\title{
A Study on the Innovation of Business Model in Manufacturing Enterprises under the Background of "Internet Plus"
}

\author{
Fanzhu Kong*, Lily Zhao \\ Business School, Huaiyin Institute of Technology, Huaian, China \\ Email: *tongjihrd@163.com
}

How to cite this paper: Kong, F.Z. and Zhao, L. (2017) A Study on the Innovation of Business Model in Manufacturing Enterprises under the Background of "Internet Plus". Open Journal of Social Sciences, 5, 43-51.

https://doi.org/10.4236/jss.2017.510004

Received: August 15, 2017

Accepted: October 10, 2017

Published: October 13, 2017

\begin{abstract}
As a new productive force, "Internet plus" is changing the modes of production. It has become a key to develop a new business model to meet "internet plus" for manufacturing industry. This paper analyzed the basic connotation and elements of the business model. On this basis, it discussed the factors that affect the innovation of the business model on the era of "Internet plus", and put forward the innovation strategy of business model from the four aspects of customer value proposition, client, enterprise and industry.
\end{abstract}

\section{Keywords}

Internet Plus, Business Model, Influencing Factors, Service Orientation

\section{Introduction}

Like it or not, as a new power, the Internet is shaping our lives and the modes of production. With the gradual development of Internet technology, the integration of the Internet and traditional industries is accelerating which is changing the industrial pattern of China. For manufacturing enterprise, its innovation ability of products and service is the biggest challenge to maintain the competitiveness and the main soft rib of the transformation and upgrade of Chinese manufacturing industry. Internet plus manufacturing industry plays an important role in the process of it. More and more enterprises have been or are making the strategy of Internet plus manufacturing industry in order to promote the transformation and upgrading of enterprises. Drucker pointed out that the competition between enterprises is no longer the product and technology, but 
the business model in the new era. The rapid development of the Internet has brought serious challenges to the traditional business model, but also provides new opportunities for the innovation of business model. Therefore, that how to help corporations create the right business model and promote the integration of internet and manufacturing industry is the key goal of this thesis. Above all, the thesis reviews and summarizes the theories of business model. With the concrete business model concept frame foundation, this article has discussed the business model innovation influence factors, the business model innovation basic way and the concrete methods.

\section{The Connotation and Element of Business Model}

\subsection{The Connotation of Business Model}

Although the research on business model has a history of several decades, the concept of business model has not formed a unified definition. The existing research can be divided into five categories: profit, management, value, strategy and synthesis. On the point of profit, business model is a kind of profit pattern of enterprise, it explains how to make money and get sustainable profit (Stewart, 2000) [1]. This definition takes into account the profit-seeking of enterprise, but it is only the most basic needs of the enterprise. Therefore, there is a lot of controversy in this definition. Later, some scholars defined the business model from the aspect of management. They believed that business model is a conceptual tool that encompasses a set of elements of product design, production, sales and service and interrelationships. It was used to explain how businesses operate and generate profits (Osterwalder, 2004) [2]. Actually, the definition ignores the difference between business model and business management. After that, some scholars proposed that business model is a kind of value creation and acquisition on the point of value creation; they thought that value creation between stakeholders is the source of profit.

The above three view is a common cognition about the business model, although it revealed the nature of profit-seeking and how to create profit, but ignored the sustainable development of enterprises. Furthermore, some scholars thought that business model is a dynamic strategy of value creation and future action based on the strategy management (Yip, 2004; Schafer, 2005) [3]. Morris (2005) put forward an integrated concept that business model is the way for enterprise to gain competitive advantage through the effective positioning and integration of internal and external elements of the enterprise. Y. X. Gu (2014) defines also the business model as a coordination mechanism between the enterprise and the environment [4] from the perspective of integration. Although business model has been defined from five different perspectives, but in fact, the boundaries of these five different concepts are not clear. Different scholars have been studied the business model and draw different conclusions in order to meet their own desires. But they are all in response to the question of "how the enterprise exists", the only difference exists in their focus. 


\subsection{The Element of Business Model}

Each concept has its own connotation and denotation. Because scholars define the business model differently, and the elements of the business model will be varying, someone who defines the business model from the point of profit emphasizes the operating profit, sources of income and market strategy. Others who define the business model on the view of management focus on integration of internal factors. The others divided business model into resource model and revenue model based on the theory of value creation. Strategy management specialists thought that strategic choice and competition strategy is the most important element of business model. Although different specialist define the business model based on the different theory, almost of them have recognized the customer value proposition, profit model, resources and capabilities, value chain should be included in the business model. Mark (2010) put forward the four factor model of business model, including customer value, core resources, core procedure and profit model.

Customer value proposition is to provide a suitable program for the customer to solve their specific problem, including target customers, customers' problem, and possible solutions. The core resource including human resource, products and equipment, pathways and brands and so on which play a key role in solving customer's problems or meet customer demand. The core procedure is the process of value creation including human training, production, planning, sales, and company's rules and regulations. The profit model is how enterprise to create value for customers and themselves, including revenue structure, cost structure, gross profits the structure and flow of resources etc. These four factors make up the cornerstone of enterprise management, enterprises should try best to design a relatively stable system in order to create value through integrate the four elements efficiently.

\section{The Influence Factors of Business Model Innovation of Manufacturing Enterprises}

Innovation is a kind of destructive change, which means that it is necessary to change the original model, and that innovation is always associated with risks and uncertainties [5]. As a result, innovation is a high-risk activity and may suffer a lot of resistance. Because of this, innovation is usually accompanied by drastic changes in the internal and external environment which the enterprise was in. Business model innovation means to change the old profit model of enterprises. So that it would be driven or restricted by different factors. Generally, the influence factors of business model innovation can be divided into external and internal.

\subsection{External Influence Factor}

Market demand is the foundation of enterprise survival, so that the change of market demand would be the first factor of business model innovation. The 
market demand is relatively stable on the era of the traditional industrial production, large-scale and continuous line production was used in reducing production costs in order to maintain competitive edge and make profits. At the same time, the enterprises put major effort to innovate technology, driven by cost reduction and efficiency improvement. However, in the internet era, consumers' demand increasingly diversified, personalized and heterogeneity, this led to the transformation of production. In other word, the enterprises should develop a new business model to meet the new market demands.

The new technology is also an important influence factor of business model innovation [6]. The three industrial revolutions have proved that new technology is an important factor in promoting enterprise change. Some scholars have pointed out that the fourth industrial revolution represented by the "internet plus" has occur [7]. The popularization and application of Internet plus will change the ecological pattern of enterprise competition. The enterprises should develop a new corresponding business model in order to meet new technology and promote the application of new technology. The integration between internet plus and manufacturing industry force enterprise to change from product-centered business model to customer service-centered business model.

Public policy is also an important influence factor of business model innovation. Enterprises are not only economic units but also social units. As a member of society, the enterprise must follow the social norms which consist of public policy especial industry policy and other social rule. The history of the world industry shows that industry policy plays vital role in industrial revolution. In the initial stage, the new things were always weak, and its advantages couldn't be fully displayed. At that time, it needs the care and support from the government policy. E-government is the product of government e-commerce policy [8]. Now, many policies have been carried out so as to integrate internet plus and manufacturing industry in china, such as the "Made in China 2025" plan. These public industry policies would affect business model innovation of manufacturing enterprises.

\subsection{Internal Influence Factor}

Industry factors which are intermediate factors in the boundaries of an enterprise would also affect business model innovation of the enterprises, which in different industry varies in operating mode, technical requirements and business change and so on. The knowledge-using industry, capital-using industry and labor-using industry is different in the production mode, target customer requirements, asset allocation ratio, market stability. In addition, the position of the enterprise in the industry may also be an influence factor of business model innovation. Industry leaders tend to maintain original business model because of their inertia. Industry followers may also take imitation learning and adopt a business model that is similar to the leader. Competitor tends to innovate business model in order to go beyond and develop competitive advantage.

Business strategy and philosophy. As an independent economic entity, each 
enterprise will have its own development strategy and business philosophy, and different strategies and ideas will have a different business model with the matching to ensure that the strategic objectives can be achieved. The strategic view that the business model is the embodiment of corporate strategy. Therefore, the business strategy will be one of the factors that affect business model innovation. If the corporate strategy is towards stability and conservatism, the innovation of business model would be slower. However, if the corporate strategy focuses on development and progress, the business model innovation will be more active. In addition, different types of corporate strategy may also be the influential factors of business model innovation. Differentiated strategies, competitive strategies, and leading strategies have different implementation models.

The relationship of the stakeholders. In the modern enterprise management system, decision-making and management is usually fragmented, controlled by different interest groups. As mentioned above, the business model contains the profit model. When the enterprises' profit keeps on growing, the stakeholders will be due to the profits and continue to maintain the original business model, even if the manager found a new business opportunity or foresee the threat of the future. The GREE Electric Appliances, INC of ZHUHAI is a good example. Ms Dong who is general manager of the GREE tries her best to develop automobile industry, but failed because of the stakeholders. Therefore, the relationship between stakeholders will become the influencing factors of the business model innovation.

Entrepreneur personality is also an influence factor of business model innovation. Schumpeter pointed out that innovation is the fundamental force of economic development, and it can not only create profits but also change the original business model, and entrepreneurs are the soul in the process of innovation. The entrepreneurs who tend to innovation will try his best to integrate the different resource in order to meet the changing environment through develop new business model based on the needs of enterprises and external business environment.

\section{Strategy of Business Model Innovation Based on Internet Plus}

The business model not only describes the relationship between the enterprise and the customer, but also reflects the combination of internal resources. From this point of view, we can draw out that business model innovation is the reorganization of business model elements. Many scholars have also discussed the business model innovation, and made many meaningful conclusions. However, this research paradigm is based on that business model elements remain unchanged and the environment is relatively stable, when the external environment changes drastically. So that the extension of the business model can be extended, the composition of its elements will change. In such a situation, the original research paradigm will not be applied. Someone pointed out that every technology 
revolution has formed a corresponding technical and economic paradigm. Therefore, "Internet+" will promote the original business model change into a number of new models which are suitable for integration between internet plus and manufacturing industry.

\subsection{The Characteristics of Internet Plus Manufacturing}

As a new economy form, "Internet plus" is widely used in various areas of the real economy, and then transform the development mode of traditional industries. At present, internet plus manufacturing has shown some new trend in china. The enterprises should understand it totally and adapt to the trend in order to ensure that the innovation of business model fit their own practice and business environment.

First, intelligent manufacturing has become the mainstream of product production. The "Made in China 2025" made clear that intelligent manufacturing is the direction of China's manufacturing industry, put forward to promote the integration of information technology and industrialization, focus on the development of intelligent equipment and intelligent products, promote the intelligent production process, cultivate new production way, and comprehensively enhance the intelligent level of the $\mathrm{R} \& \mathrm{D}$, production, management and service. MIIT of China has started the experimental unit job of Internet plus industry in 2015 which focus on cultivating the business model based on Internet. All this shows that the traditional industrial production mode is gone, intelligent manufacturing will become the mainstream of the future manufacturing industry.

Second, the internet marketing has become the most important channel for product sales. With the popularity of the Internet, especially mobile Internet technology, more and more consumers obtain product information, buy products, and share product experience through internet. The internet marketing could reduce greatly the physical and psychological Distance between enterprises and consumers, so that more and more enterprises have adapted the internet marketing. The universality and cross-boundary of internet not only makes internet marketing possible, but also to promote the enterprise from the domestic market to the international market.

Third, $\mathrm{O} 2 \mathrm{O}$ business model has been popular. The combination of virtual and physical network has created a large number of $\mathrm{O} 2 \mathrm{O}$ business models. Many enterprises integrate online resource and offline resource to develop new production types such as personalized customization by use of $\mathrm{O} 2 \mathrm{O}$ platform. For example, Qingdao Haier has put forward the platform business mode which consists of "enterprise platform", employee entrepreneurship, and the user personalization [9]. The Haier has changed the original organizational structure into an open platform in where employees could obtain customer demand information and share with each other.

Fourth, the thinking of open service has gradually formed. The Internet makes it possible for different regions, different types, different sizes, different indus- 
tries and related institutions to cooperate. At the same time, more and more enterprises are looking for diversified partners to meet the increasing diversified personalized needs of customers. At present, the customer's demand has also been divorced from the simple functional consumption. The service value attached to the product is gradually increasing along with the consumer rights and service awareness enhancement. It is a urgent task for enterprises to change the original business philosophy of "product-oriented" into "open service-oriented".

\subsection{Innovation Strategy of Manufacturing Enterprise Business Model}

First, make clear customer value proposition. It should be the focus of business model innovation to serve customer in the most appropriate way, because the enterprise would achieve its business goals only by meeting customer needs. Most of manufacturing enterprises in china still remain "product-oriented" business model, focusing on technology innovation and developing new product, while ignoring the inherent needs of customers. In order to meet the new market environment, enterprises should firstly make clear the customer demand, and to carry out technology innovation and product development based on the real needs of market, and then to achieve internal and external environmental coordination, which is the base of business model innovation.

Second, build information platform with internet. In fact, Internet era is also the information age, it is important for enterprises to abstain diversified information about market, customer, technology, public policy, and so on in time for competitive advantage [10]. To this end, enterprises can rely on the Internet to construct information platform in where they can communicate freely with customers, government and other persons. Thus, not only the enterprises could understand the customers' real need and feedback, but also the customers could grasp the information about product design and production before they decide to buy [11]. Finally, it is worthy of note that no one mode can be applied in every platform, the enterprises can develop special platform according to industry environment and their own characteristics.

Third, build platform of double creations based on internet. Innovation and entrepreneurship has become the most important driving force for economic development, and will be indispensable tool for long-term development of the enterprise [12]. The construction of double creation platform consists of two purposes. Above all, to achieve effective convergence of external information platform and internal double creation platform, integrate internal innovation \& entrepreneurship and the reel needs of market, and carry the construction of double creations platform oriented market demand, rather than the traditional product-oriented technology innovation. Second, the double creations platform is a thought collision platform, aimed at the full communication and exchange of innovation thoughts, which requires the company to change the original organizational structure and staff management in order to create organizational environment in favor of innovation, so that the staff are not only willing to in- 
novate, but also can act on it.

Fourth, Seeking cross-border integration with the Internet business. Internet-based industrial upgrading always requires a lot of basic resources [13]. It is a good idea for the SMEs to cooperate with Internet business during the process of integration; it can not only reduce resource investment, but also speed up the integration of Internet+ manufacturing. In the process of cross-border integration, the manufacturing enterprises can take the joint-venture, cooperation, outsourcing and other means to cultivate new business entities, to establish the integration of the development of the technical system, to establish the technical system, standard system and business model which match with integration in order to achieve the manufacturing capacity of online distribution, transaction. The manufacturing enterprises can also cooperate with the Internet business to carry out strategic investment, brand development, internet marketing and other business areas.

\section{Conclusion}

Business model is a balance between the internal and external environment of the enterprise. It is the result of the interaction of various forces, and must match the specific business environment. With the change of the economic environment, enterprises should adjust their business models to adapt to the new situation. In the background of Internet plus, making the business model innovation is related to the long-term development of enterprises. The manufacturing enterprises should fully understand the impact of Internet plus on the development of manufacturing industry, and develop the special business model on the base of internal and external environment.

\section{Acknowledgements}

The paper was sponsored by Qing Lan Project of Jiangsu Province, National Statistical Research Project "Study on the innovation of business model in manufacturing enterprises in the background of new economy (2016486), the Philosophy and Social Science Fund of Education Department of Jiangsu Province (2016SJB630127), Social Science Fund of Huaiyin Institute of Technology (20150036).

\section{References}

[1] Stewart, D.W. and Zhao, Q. (2000) Internet Marketing, Business Model, and Public Policy. Journal of Public Policy and Marketing, No. 19, 287-296. https://doi.org/10.1509/jppm.19.2.287.17125

[2] Osterwalde, A. (2004) The Business Model Ontology a Proposition in a Design Science Approach. Escaladers Haunts Etudes Commercial Universite, No. 6, 678-688.

[3] Yin, G.S. (2004) Using Strategy to Change Your Business Mode. Business Strategy Review, No. 2, 17-24.

[4] Gu, Y.X. (2014) The Logic of Business Model Design. Tsinghua University Press, Beijing. 
[5] Wang, Y.F. and Cao, Y. (2013) Study on the Influence Factors of Business Model Innovation of Small and Micro-sized Sci-Tech Enterprises. Science \& Technology Progress and Policy, No. 18, 13-17.

[6] Zhang, L.L. (2014) Study on the Influence Factor of Business Model Innovation. Anhui University, Hefei.

[7] Chen, C. and Che, Y.J. (2016) Internet Platfrom Mode and Traditional Firms' Reconstruction. Science \& Technology Progress and Policy, No. 6, 84-87.

[8] Rong ,K., Hu, G.Y. and Lin, Y. (2014) Understanding Business Ecosystem Using 6C Framework in Internet-of-Things-Based Sectors. International Journal of Production Economics, No. 4, 21-32.

[9] Hu, Y. and Hao, Y.Z. (2014) The Thought of Zhang Ruimin. China Machine Press, Beijing

[10] Li, H.J., Tian, Y.X. and Li, W.J. (2014) Mobile Internet Thinking and Traditional Business Reengineering. China Industrial Economics, No. 10, 135-146.

[11] Jian, Z.Q. and Zhang, L.C. (2017) Servitization Transformation of Manufacturing Enterprise Based on Business Model Innovation: Taking GRG Banking Company as an Example. Science and Technology Management Research, No. 6, 13-20.

[12] Luo, M. and Li, L.Y. (2015) The Innovation of Business Model in Internet Era: From Value Creation Perspertive. China Industrial Economics, No. 1, 95-107.

[13] Qiu, F.S. (2017) Construction of Intelligent Supply Chain for Intelligent Manufacturing. Logistics Technology and Apply, No. 3, 92-97. 